\title{
Magnetic Switching in Vapochromic Oxalato-Bridged 2D Copper(II)-Pyrazole Compounds for Biogenic Amine Sensing ${ }^{\dagger}$
}

\author{
Nadia Marino ${ }^{1, *(0)}$, María Luisa Calatayud ${ }^{2}$, Marta Orts-Arroyo ${ }^{2}$, Alejandro Pascual-Álvarez ${ }^{2}$, Nicolás Moliner ${ }^{2}$, \\ Miguel Julve ${ }^{2, *}$, Francesc Lloret ${ }^{2}$, Giovanni De Munno ${ }^{1}$ (D), Rafael Ruiz-García ${ }^{2}$ and Isabel Castro ${ }^{2, *(D)}$
}

1 Dipartimento di Chimica e Technologie Chemiche, Università della Calabria, 87036 Rende, Italy; demunno@unical.it

2 Instituto de Ciencia Molecular (ICMol), Universitat de València, C/Catedrático José Beltrán 2, 46980 Valencia, Spain; marialuisacalatayud@gmail.com (M.L.C.); martaorts.a@gmail.com (M.O.-A.); alejandro.pascual@uv.es (A.P.-Á.); Fernando.moliner@uv.es (N.M.); francisco.lloret@uv.es (F.L.); rafael.ruiz@uv.es (R.R.-G.)

* Correspondence: nadia.marino@unical.it (N.M.); miguel.julve@uv.es (M.J.); isabel.castro@uv.es (I.C.)

+ In memoriam Professor Peter Day, one of the most respected inorganic chemists whose impact as academic and scientist can only be described in the highest praise, on his passing last May 2020. We are sure his legacy will have long-lasting effects.

Citation: Marino, N.; Calatayud, M.L.; Orts-Arroyo, M.;

Pascual-Álvarez, A.; Moliner, N.; Julve, M.; Lloret, F.; De Munno, G.; Ruiz-García, R.; Castro, I. Magnetic Switching in Vapochromic OxalatoBridged 2D Copper(II)-Pyrazole Compounds for Biogenic Amine Sensing. Magnetochemistry 2021, 7, 65. https://doi.org/10.3390/ magnetochemistry7050065

Academic Editors: Lee Martin, Scott Turner, John Wallis, Hiroki Akutsu and Carlos J. Gómez García

Received: 28 April 2021

Accepted: 8 May 2021

Published: 12 May 2021

Publisher's Note: MDPI stays neutral with regard to jurisdictional claims in published maps and institutional affiliations.

Copyright: $\odot 2021$ by the authors. Licensee MDPI, Basel, Switzerland. This article is an open access article distributed under the terms and conditions of the Creative Commons Attribution (CC BY) license (https:// creativecommons.org/licenses/by/ $4.0 /)$.

\begin{abstract}
A new two-dimensional (2D) coordination polymer of the formula $\left\{\mathrm{Cu}(\mathrm{ox})(4-\mathrm{Hmpz}) \cdot 1 / 3 \mathrm{H}_{2} \mathrm{O}\right\}_{n}$ (1) (ox = oxalate and 4-Hmpz = 4-methyl- $1 H$-pyrazole) has been prepared, and its structure has been determined by single-crystal X-ray diffraction. It consists of corrugated oxalato-bridged copper(II) neutral layers featuring two alternating bridging modes of the oxalate group within each layer, the symmetric bis-bidentate $\left(\mu-\kappa^{2} \mathrm{O}^{1}, \mathrm{O}^{2}: \kappa^{2} \mathrm{O}^{2^{\prime}}, \mathrm{O}^{1^{\prime}}\right)$ and the asymmetric bis(bidentate/monodentate) $\left(\mu_{4}-\kappa O^{1}: \kappa^{2} O^{1}, O^{2}: \kappa O^{2^{\prime}}: \kappa^{2} O^{2^{\prime}}, \mathrm{O}^{1^{\prime}}\right)$ coordination modes. The three crystallographically independent six-coordinate copper(II) ions that occur in $\mathbf{1}$ have tetragonally elongated surroundings with three oxygen atoms from two oxalate ligands, a methylpyrazole-nitrogen defining the equatorial plane, and two other oxalate-oxygen atoms occupying the axial positions. The monodentate 4-Hmpz ligands alternatively extrude above and below each oxalate-bridged copper(II) layer, and the water molecules of crystallization are located between the layers. Compound 1 exhibits a fast and selective adsorption of methylamine vapors to afford the adsorbate of formula $\left\{\mathrm{Cu}(\mathrm{ox})(4-\mathrm{Hmpz}) \cdot 3 \mathrm{MeNH}_{2} \cdot 1 / 3 \mathrm{H}_{2} \mathrm{O}\right\}_{n}$ (2), which is accompanied by a concomitant color change from cyan to deep blue. Compound 2 transforms into $\left\{\mathrm{Cu}(\mathrm{ox})(4-\mathrm{Hmpz}) \cdot \mathrm{MeNH}_{2} \cdot 1 / 3 \mathrm{H}_{2} \mathrm{O}_{n}\right.$ (3) under vacuum for three hours. The cryomagnetic study of $\mathbf{1}-\mathbf{3}$ revealed a unique switching from strong (1) to weak (2 and $\mathbf{3})$ antiferromagnetic interactions. The external control of the optical and magnetic properties along this series of compounds might make them suitable candidates for switching optical and magnetic devices for chemical sensing.
\end{abstract}

Keywords: copper; oxalate; pyrazole; crystal structure; 2D coordination polymers; magnetic properties; sorption properties; amine sensing

\section{Introduction}

The design and synthesis of molecule-based multifunctional magnetic materials has opened new possibilities in the field of molecular magnetism [1,2]. The goal of this research is to explore new classes of compounds that combine two (or more) chemical and physical properties, besides the magnetic ones, which are of fundamental importance for industrial and technological applications [3-11]. New magnetic phenomena would arise from the synergy between these coexisting properties (magnetic second harmonic generation, magneto-chiral dichroism, or multiferroicity), which could eventually be further modified by the application of external stimuli (temperature, pressure, light, or chemical analytes) [10]. Such a fruitful avenue of molecular magnetism was initiated half a decade ago by Peter Day's pioneering work on polyhalide metal salts with inorganic and organic (TTF 
and BEDT-TTF derivatives) cations as examples of purely inorganic and inorganic-organic hybrid molecular magnetic materials that led to a unique class of magnetic molecular conductors $[3,4,7]$. Several research groups are currently exploring this method of acquiring new types of potentially switchable, molecule-based, multifunctional magnetic materials. Chiral and luminescent magnets; non-linear optics (NLO) magnets and multiferroics; protonic and electronic magnetic conductors; spin crossover or valence tautomeric magnets; and thermo-, piezo-, photo-, or chemoswitchable porous magnets constitute some illustrative examples. The addressing of these multifunctional molecular magnetic materials on thin films and surfaces, or their shaping as nanoparticles or nanocrystals, is mandatory for their use in nanoscience and nanotechnology in the near future. In fact, they should be integrated into devices to realize their potential applications, crossing the bridge between fundamental science and cutting-edge technological products [10].

Magnetic coordination polymers have become one of the most challenging issues among this diverse class of multifunctional molecule-based magnetic materials due to their structural tunability and potentially switchable chemical (sorption, sensing, redox, or catalytic) and physical (optical, thermal, magnetic, or conducting) properties [12-22]. This particular class of inorganic-organic hybrid porous materials, also referred to as metal-organic frameworks (MOFs), have emerged as suitable sensory materials for the detection and monitoring of gases and vapors from volatile organic compounds (VOCs) of industrial, medical, or environmental interest [23-34]. A major goal in the area of magnetic MOFs is to tune their optical, electronic, and/or magnetic properties by the inclusion of selected guests that are adsorbed through simple chemi- or physisorption processes [35-47]. Among the target molecules, ammonia, or its biogenic amine (BA) derivatives, from the simple methyl- and trimethylamine to the more complex tetramethylene- (putrescine) and pentamethylenediamine (cadaverine), are of particular interest for the future applications of magnetic coordination polymers in the chemical sensing of VOCs resulting from industrial procedures or food degradation [48-60]. Due to their unique multiresponsive and multifunctional character, magnetic MOFs are good alternatives to organic polymeric materials and their metal composites, envisaging the substitution of metal- and metal oxide-based commercial chemiresistive BA sensors, which are currently used in industrial process management and food quality control [54].

Our strategy in this field is based on the use of oxalate and pyrazole derivatives as bridging and terminal ligands, respectively, toward copper(II) ions for the preparation of heteroleptic copper(II) coordination polymers [61-63]. In fact, oxalate is a versatile polyatomic ligand because of the great number of coordination modes that it can adopt in its heteroleptic copper(II) complexes with pyrazole derivatives, depending on the steric and/or electronic effects of the pyrazole substituents [61]. Moreover, it is an efficient mediator of magnetic interactions between copper(II) ions when acting as a bridge, with the strength and nature of these interactions, either ferro- or antiferromagnetic, depending on the coordination mode of the oxalate bridge and on the geometry at the copper(II) ions $[62,63]$. Herein we focus on the synthesis and spectroscopic and magneto-structural characterization of a novel oxalato-bridged two-dimensional (2D) copper(II) coordination polymer of formula $\left\{\mathrm{Cu}(\mathrm{ox})(4-\mathrm{Hmpz}) \cdot 1 / 3 \mathrm{H}_{2} \mathrm{O}\right\}_{n}$ (1) (4-Hmpz = 4-methyl-1H-pyrazole), together with a preliminary study on its sorption properties toward polymethyl-substituted amines with different steric and/or electronic effects. Our goal is to investigate the influence of the number of methyl substituents on the adsorption behavior and eventually on the optical and magnetic properties of the resulting methylamine adsorbates of the formulae $\left\{\mathrm{Cu}(\mathrm{ox})(4-\mathrm{Hmpz}) \cdot 3 \mathrm{MeNH}_{2} \cdot 1 / 3 \mathrm{H}_{2} \mathrm{O}\right\}_{\mathrm{n}}(2)$ and $\left\{\mathrm{Cu}(\mathrm{ox})(4-\mathrm{Hmpz}) \cdot \mathrm{MeNH}_{2} \cdot 1 / 3 \mathrm{H}_{2} \mathrm{O}\right\}_{\mathrm{n}}(3)$. The color change and modification of the magnetic properties that $\mathbf{1}$ exhibits upon the selective adsorption of methylamine makes it a new prototype for a bimodal optical (colorimetric) and magnetic sensor for the selective vapor detection of biogenic amines. 


\section{Materials and Methods}

\subsection{Materials}

Oxalic acid $\left(\mathrm{H}_{2} \mathrm{Ox}\right)$, sodium oxalate $\left(\mathrm{Na}_{2} \mathrm{Ox}\right)$, 4-Hmpz, copper(II) perchlorate hexahydrate, 33\% methylamine, dimethylamine, and trimethylamine solutions in absolute ethanol, and triethylamine were of laboratory grade and were used as received.

\subsection{Preparations of 1 and Its Methylamine Adsorbates $\mathbf{2}$ and $\mathbf{3}$}

2.2.1. $\left\{\mathrm{Cu}(\mathrm{ox})(4-\mathrm{Hmpz}) \cdot 1 / 3 \mathrm{H}_{2} \mathrm{O}\right\}_{\mathrm{n}}(\mathbf{1})$

An aqueous solution $(15 \mathrm{~mL})$ of $4-\mathrm{Hmpz}(0.123 \mathrm{~g}, 1.5 \mathrm{mmol})$ was added dropwise to an aqueous solution $(20 \mathrm{~mL})$ of copper(II) perchlorate hexahydrate $(0.370 \mathrm{~g}, 1.0 \mathrm{mmol})$. $\mathrm{Na}_{2} \mathrm{Ox}(0.134 \mathrm{~g}, 1.0 \mathrm{mmol})$ dissolved in a hot aqueous solution $(10 \mathrm{~mL})$ was added dropwise to the above solution. The resulting sky blue mixture was stirred for 30 min under gentle warming. A pale blue polycrystalline solid of $\mathbf{1}$ that separated was filtered off and air-dried (0.151 g, 65\% yield). Anal. calcd for $\mathrm{C}_{6} \mathrm{H}_{6} \mathrm{~N}_{2} \mathrm{CuO}_{4} \cdot 1 / 3 \mathrm{H}_{2} \mathrm{O}\left(\mathrm{MW}=239.7 \mathrm{~g} \mathrm{~mol}^{-1}\right): \mathrm{C}$, 30.07; H, 2.80; N, 11.69\%. Found: C, 29.27; H, 2.75; N, 11.65\%. IR ( $\left.\mathrm{KBr} / \mathrm{cm}^{-1}\right)$ : 3496w [v(O-H) from water], 3404m [v(N-H) from 4-Hmpz], 3189w and 2926w [v(C-H) from 4-Hmpz], 1706s, 1651s and 1599vs [ $v_{\mathrm{as}}(\mathrm{CO})$ from ox], 1358m, 1317w and 1297s [ $v_{\mathrm{s}}(\mathrm{CO})$ from $\mathrm{ox}]$ and $820 \mathrm{~m}$ and $803 \mathrm{~m}[\delta(\mathrm{OCO})$ from ox]. When using an aqueous solution $(10 \mathrm{~mL})$ of $\mathrm{H}_{2} \mathrm{Ox}(0.045 \mathrm{~g}, 0.5 \mathrm{mmol})$ and $\mathrm{Et}_{3} \mathrm{~N}(0.14 \mathrm{~mL}, 1.0 \mathrm{mmol})$ instead of sodium oxalate, a small amount of tiny pale greenish blue platelets of $\mathbf{1}$, suitable for X-ray analysis, were grown by slow evaporation of the filtered aqueous solutions upon standing at room temperature for several days.

\subsection{2. $\left\{\mathrm{Cu}(\mathrm{ox})(4-\mathrm{Hmpz}) \cdot 3 \mathrm{MeNH}_{2} \cdot 1 / 3 \mathrm{H}_{2} \mathrm{O}\right\}_{n}(2)$}

A polycrystalline sample of $1(0.120 \mathrm{~g}, 0.5 \mathrm{mmol})$ was placed in a Schlenk flask connected to an argon current that had previously flowed through a bubbler filled with a $33 \% \mathrm{MeNH}_{2}$ solution in absolute ethanol $(25 \mathrm{~mL})$, and transformed into a deep blue powder of 2 after $3 \mathrm{~h}$ of exposure at room temperature. Anal. calcd for $\mathrm{C}_{9} \mathrm{H}_{21} \mathrm{~N}_{5} \mathrm{CuO}_{4} \cdot 1 / 3 \mathrm{H}_{2} \mathrm{O}$ $\left(\mathrm{MW}=332.7 \mathrm{~g} \mathrm{~mol}^{-1}\right)$ : C, 32.48; H, 6.56; N, 21.04\%. Found: C, 32.79; H, 6.59; N, 20.99\%; IR $\left(\mathrm{KBr} / \mathrm{cm}^{-1}\right): 3497 \mathrm{w}\left[\left(\mathrm{v}(\mathrm{O}-\mathrm{H})\right.\right.$ from water] 3405m [v(N-H) from 4-Hmpz and $\left.\mathrm{MeNH}_{2}\right]$, $3101 \mathrm{w}$ and $2971 \mathrm{w}$ [ $v(\mathrm{C}-\mathrm{H})$ from $4-\mathrm{Hpmz}$ and $\left.\mathrm{MeNH}_{2}\right], 1674 \mathrm{vs}, 1652 \mathrm{~s}$ and $1637 \mathrm{~s}\left[\mathrm{v}_{\mathrm{as}}(\mathrm{CO})\right.$ from ox], 1418s $\left[v(\mathrm{C}-\mathrm{H})_{\text {bending }}\right.$ from $\left.\mathrm{MeNH}_{2}\right], 1370 \mathrm{~m}$ and $1289 \mathrm{~s}\left[v_{\mathrm{s}}(\mathrm{CO})\right.$ from ox $], 928 \mathrm{~m}$ $\left[v(\mathrm{C}-\mathrm{N})_{\text {stretching }}\right.$ from $\left.\mathrm{MeNH}_{2}\right]$, and $829 \mathrm{~m}$ and $807 \mathrm{~m}[\delta(\mathrm{OCO})$ from ox].

\subsection{3. $\left\{\mathrm{Cu}(\mathrm{ox})(4-\mathrm{Hmpz}) \cdot \mathrm{MeNH}_{2} \cdot 1 / 3 \mathrm{H}_{2} \mathrm{O}\right\}_{\mathrm{n}}$ (3)}

Treatment of $2(0.166 \mathrm{~g}, 0.5 \mathrm{mmol})$ under vacuum for $3 \mathrm{~h}$ gave a grayish deep blue powder of 3. Anal. calcd for $\mathrm{C}_{7} \mathrm{H}_{11} \mathrm{~N}_{3} \mathrm{CuO}_{4} \cdot 1 / 3 \mathrm{H}_{2} \mathrm{O}\left(\mathrm{MW}=270.7 \mathrm{~g} \mathrm{~mol}^{-1}\right)$ : $\mathrm{C}, 31.05 ; \mathrm{H}$, 4.34; N, 15.52\%. Found: C, 31.03; H, 4.40; N, 15.37\%; IR $\left(\mathrm{KBr} / \mathrm{cm}^{-1}\right): 3497 \mathrm{w}[(v(\mathrm{O}-\mathrm{H})$ from water], 3407m [v(N-H) from 4-Hmpz and $\left.\mathrm{MeNH}_{2}\right], 3103 \mathrm{w}$ and $2950 \mathrm{w}[\mathrm{v}(\mathrm{C}-\mathrm{H})$ from Hpmz and $\left.\mathrm{MeNH}_{2}\right], 1675 \mathrm{vs}, 1652 \mathrm{~s}$ and $1637 \mathrm{~s}\left[v_{\mathrm{as}}(\mathrm{CO})\right.$ from ox], $1418 \mathrm{~s} \mathrm{~cm}^{-1}\left[v(\mathrm{C}-\mathrm{H})_{\text {bending }}\right.$ from

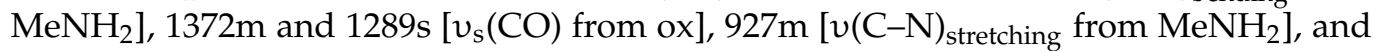
$830 \mathrm{~m}$ and $806 \mathrm{~m}[\delta(\mathrm{OCO})$ from ox].

\subsection{Vapor Adsorption Studies}

The vapor adsorption kinetic measurements were carried out on different aliquots containing powdered polycrystalline samples of $\mathbf{1}(0.024 \mathrm{~g}, 0.1 \mathrm{mmol})$ at room temperature in a Schlenk flask connected to an argon current that had previously flowed through a bubbler filled with either $33 \% \mathrm{MeNH}_{2}, \mathrm{Me}_{2} \mathrm{NH}$, or $\mathrm{Me}_{3} \mathrm{~N}$ solutions in absolute ethanol. The amine contents were determined by elemental analysis of the corresponding samples after 1, 6, 20,60, and $180 \mathrm{~min}$ of exposure to the amine-saturated argon flow.

\subsection{Physical Techniques}

Elemental analyses $(\mathrm{C}, \mathrm{H}, \mathrm{N})$ were performed by the Servei Central de Suport a la Investigació Experimental de la Universitat de València. FT-IR spectra were recorded 
on a Nicolet-5700 spectrophotometer as KBr pellets. X-ray powder diffraction (XRPD) patterns of powdered polycrystalline samples were collected at room temperature on a D8 Avance A25 Bruker diffractometer by using graphite-monochromated $\mathrm{Cu}-\mathrm{K} \alpha$ radiation $(\lambda=1.54056 \AA)$. Variable-temperature (2.0-300 K) magnetic susceptibility measurements were carried out with a SQUID magnetometer under applied fields of $5.0 \mathrm{kOe}(T>20$ $\mathrm{K})$ and $250 \mathrm{Oe}(T<20 \mathrm{~K})$ to prevent any saturation effect at low temperature. The powdered polycrystalline samples were embedded on $n$-eicosane and placed in small sealed plastic bags to prevent any solvent loss during the magnetic measurements. The experimental magnetic susceptibility data were corrected for the diamagnetic contributions of the constituent atoms and the sample holder, as well as for the temperature-independent paramagnetism (tip) of the $\mathrm{Cu}^{\mathrm{II}}$ ion $\left(60 \times 10^{-6} \mathrm{~cm}^{3} \mathrm{~mol}^{-1}\right)$.

\subsection{X-ray Crystallographic Data Collection and Structure Refinement}

X-ray crystallographic data for 1 were collected with a Bruker-AXS SMART CCD diffractometer at $98 \mathrm{~K}$ using graphite monochromated $\mathrm{Cu}-\mathrm{K} \alpha$ radiation $(\lambda=1.54178 \AA)$. The crystal selected for data collection, a tiny single-laminar fragment with approximate dimensions of $0.005 \times 0.050 \times 0.110 \mathrm{~mm}$, was coated with Paraton oil to prevent any potential solvent loss, attached to a glass fiber, and quickly transferred under the cold nitrogen stream of the diffractometer. The Bruker SMART and SAINT softwares were employed for data collection and integration, respectively. Empirical absorption corrections were calculated using SADABS [64-66]. The structures were solved by direct methods and subsequently completed by Fourier recycling using the SHELXTL software packages $[67,68]$ and refined by the full-matrix least-squares refinements based on $F^{2}$ with all observed reflections. All non-hydrogen atoms were refined anisotropically. The hydrogen atoms of the 4-Hmpz ligands were set in calculated positions and refined using a riding model. The hydrogen atoms on the water molecule of crystallization were located on the $\Delta F$ map and refined with restraints on the $\mathrm{O}-\mathrm{H}$ and $\mathrm{H} \cdots \mathrm{H}$ distances, with the thermal factors fixed to $0.05 \AA^{2}$. The final geometrical calculations and graphical manipulations were performed using the XP utility within SHELX and the Diamond program [69]. Crystal data for 1 are summarized in Table 1 . Selected bond distances and angles and hydrogen bonds for $\mathbf{1}$ are listed in Tables 2 and 3, respectively. The value of $Z$ reported in Table $1(Z=12)$ refers to the formula $\left\{\mathrm{Cu}(\mathrm{ox})(4-\mathrm{Hmpz}) \cdot 1 / 3 \mathrm{H}_{2} \mathrm{O}\right\}_{n}$; the asymmetric unit for $\mathbf{1}$ comprises three crystallographically independent copper(II) ions with analogous coordination environments, and one water molecule of crystallization $\left[\mathrm{Z}=4\right.$ for $\left.\left\{[\mathrm{Cu}(\mathrm{ox})(4-\mathrm{Hmpz})]_{3} \cdot \mathrm{H}_{2} \mathrm{O}\right\}_{n}\right]$. The CCDC reference number is 2079936.

Table 1. Summary of crystal data and structure refinement for $\mathbf{1}$.

\begin{tabular}{cc} 
Formula & $\mathrm{C}_{6} \mathrm{H}_{6.67} \mathrm{CuN}_{2} \mathrm{O}_{4.33}$ \\
Fw & 239.66 \\
Crystal system & Monoclinic \\
Space group & $P 2_{1} / c$ \\
$a / \AA$ & $9.9554(5)$ \\
$b / \AA$ & $9.3037(4)$ \\
$c / \AA$ & $25.2695(12)$ \\
$\beta /{ }^{\circ}$ & $94.670(3)$ \\
$V / \AA^{3}$ & $2332.74(19)$ \\
$Z$ & 12 \\
$D_{c} / \mathrm{g} \mathrm{cm}^{-3}$ & 2.047 \\
$T / \mathrm{K}$ & $90(2)$ \\
$\mu / \mathrm{mm}^{-1}$ & 3.949 \\
$F(000)$ & 1444 \\
Refl. Collected & 22,317 \\
Refl. indep. $\left[R_{\text {int }}\right]$ & $3947[0.0592]$ \\
Refl. obs. $[I>2 \sigma(I)]$ & 2956 \\
Goodness-of-fit on $F^{2}$ & 1.079 \\
\hline
\end{tabular}


Table 1. Cont.

\begin{tabular}{cc}
\hline$R_{1}{ }^{\mathrm{a}}[I>2 \sigma(I)]($ all $)$ & $0.0497(0.0690)$ \\
$w R_{2}{ }^{\mathrm{b}}[I>2 \sigma(I)]($ all $)$ & $0.1309(0.1422)$ \\
$\Delta \rho_{\max , \min } / \mathrm{e} \AA^{-3}$ & 0.973 and -0.432 \\
\hline${ }^{\mathrm{a}} R_{1}=\sum|| F_{\mathrm{o}}|-| F_{\mathrm{c}}|| / \sum\left|F_{\mathrm{o}}\right| .^{\mathrm{b}} w R_{2}=\left\{\sum w\left(F_{\mathrm{o}}{ }^{2}-F_{\mathrm{c}}{ }^{2}\right)^{2} / \sum\left[w\left(F_{\mathrm{o}}{ }^{2}\right)^{2}\right\}^{1 / 2}\right.$ & and $w=1 /\left[\sigma^{2}\left(F_{\mathrm{o}}\right)^{2}+(m P)^{2}+n P\right]$ with \\
$P=\left(F_{\mathrm{o}}{ }^{2}+2 F_{\mathrm{c}}{ }^{2}\right) / 3, m=0.0633$ and $n=7.8872$. &
\end{tabular}

Table 2. Selected bond distances $(\AA)$ and angles $\left({ }^{\circ}\right)$, and intra- and inter-chain $\mathrm{Cu} \cdots$ Cu distances $(\AA)$ for $\mathbf{1}^{1}$.

\begin{tabular}{|c|c|c|c|c|c|}
\hline \multicolumn{2}{|c|}{$\mathrm{Cu}(1)$ environment } & \multicolumn{2}{|c|}{$\mathrm{Cu}(2)$ environment } & \multicolumn{2}{|c|}{$\mathrm{Cu}(3)$ environment } \\
\hline $\mathrm{Cu}(1)-\mathrm{N}(1)$ & $1.985(4)$ & $\mathrm{Cu}(2)-\mathrm{N}(3)$ & $1.983(4)$ & $\mathrm{Cu}(3)-\mathrm{N}(5)$ & $1.982(4)$ \\
\hline $\mathrm{Cu}(1)-\mathrm{O}(1)$ & $1.969(3)$ & $\mathrm{Cu}(2)-\mathrm{O}(6)$ & $1.961(3)$ & $\mathrm{Cu}(3)-\mathrm{O}(8 \mathrm{~d})$ & $1.968(3)$ \\
\hline $\mathrm{Cu}(1)-\mathrm{O}(3)$ & $1.984(3)$ & $\mathrm{Cu}(2)-\mathrm{O}(10)$ & $1.998(3)$ & $\mathrm{Cu}(3)-\mathrm{O}(11)$ & $1.993(3)$ \\
\hline $\mathrm{Cu}(1)-\mathrm{O}(4 \mathrm{~b})$ & $2.010(3)$ & $\mathrm{Cu}(2)-\mathrm{O}(9)$ & $1.978(3)$ & $\mathrm{Cu}(3)-\mathrm{O}(12)$ & $1.991(3)$ \\
\hline $\mathrm{Cu}(1)-\mathrm{O}(5)$ & $2.388(3)$ & $\mathrm{Cu}(2)-\mathrm{O}(7 \mathrm{c})$ & $2.561(3)$ & $\mathrm{Cu}(3)-\mathrm{O}(2)$ & $2.527(3)$ \\
\hline $\mathrm{Cu}(1)-\mathrm{O}(2 \mathrm{a})$ & $2.428(3)$ & $\mathrm{Cu}(2)-\mathrm{O}(5)$ & $2.317(3)$ & $\mathrm{Cu}(3)-\mathrm{O}(7 \mathrm{~d})$ & $2.287(3)$ \\
\hline $\mathrm{O}(1)-\mathrm{Cu}(1)-\mathrm{N}(1)$ & 97.70(15) & $\mathrm{O}(6)-\mathrm{Cu}(2)-\mathrm{N}(3)$ & $93.96(15)$ & $\mathrm{O}(8 \mathrm{~d})-\mathrm{Cu}(3)-\mathrm{N}(5)$ & $95.18(15)$ \\
\hline $\mathrm{O}(1)-\mathrm{Cu}(1)-\mathrm{O}(2 \mathrm{a})$ & $75.08(12)$ & $\mathrm{O}(6)-\mathrm{Cu}(2)-\mathrm{O}(5)$ & $78.54(12)$ & $\mathrm{O}(8 \mathrm{~d})-\mathrm{Cu}(3)-\mathrm{O}(7 \mathrm{~d})$ & $79.09(12)$ \\
\hline $\mathrm{O}(1)-\mathrm{Cu}(1)-\mathrm{O}(5)$ & $94.19(12)$ & $\mathrm{O}(6)-\mathrm{Cu}(2)-\mathrm{O}(7 \mathrm{c})$ & $88.96(12)$ & $\mathrm{O}(8 \mathrm{~d})-\mathrm{Cu}(3)-\mathrm{O}(2)$ & $91.07(12)$ \\
\hline $\mathrm{O}(1)-\mathrm{Cu}(1)-\mathrm{O}(3)$ & 90.90(13) & $\mathrm{O}(6)-\mathrm{Cu}(2)-\mathrm{O}(9)$ & $91.76(13)$ & $\mathrm{O}(8 \mathrm{~d})-\mathrm{Cu}(3)-\mathrm{O}(12)$ & 89.94(13) \\
\hline $\mathrm{O}(1)-\mathrm{Cu}(1)-\mathrm{O}(4 \mathrm{~b})$ & $172.64(13)$ & $\mathrm{O}(6)-\mathrm{Cu}(2)-\mathrm{O}(10)$ & $176.00(13)$ & $\mathrm{O}(8 \mathrm{~d})-\mathrm{Cu}(3)-\mathrm{O}(11)$ & $173.95(13)$ \\
\hline $\mathrm{O}(3)-\mathrm{Cu}(1)-\mathrm{N}(1)$ & $170.77(15)$ & $\mathrm{O}(9)-\mathrm{Cu}(2)-\mathrm{N}(3)$ & 173.60(14) & $\mathrm{O}(12)-\mathrm{Cu}(3)-\mathrm{N}(5)$ & $174.88(14)$ \\
\hline $\mathrm{O}(3)-\mathrm{Cu}(1)-\mathrm{O}(5)$ & $88.91(12)$ & $\mathrm{O}(9)-\mathrm{Cu}(2)-\mathrm{O}(7 \mathrm{c})$ & $83.13(11)$ & $\mathrm{O}(12)-\mathrm{Cu}(3)-\mathrm{O}(2)$ & $87.89(11)$ \\
\hline $\mathrm{O}(3)-\mathrm{Cu}(1)-\mathrm{O}(2 \mathrm{a})$ & $86.76(12)$ & $\mathrm{O}(9)-\mathrm{Cu}(2)-\mathrm{O}(5)$ & $86.99(12)$ & $\mathrm{O}(12)-\mathrm{Cu}(3)-\mathrm{O}(7 \mathrm{~d})$ & $91.32(12)$ \\
\hline $\mathrm{O}(3)-\mathrm{Cu}(1)-\mathrm{O}(4 \mathrm{~b})$ & $83.28(13)$ & $\mathrm{O}(9)-\mathrm{Cu}(2)-\mathrm{O}(10)$ & $84.32(13)$ & $\mathrm{O}(11)-\mathrm{Cu}(3)-\mathrm{O}(12)$ & $84.10(13)$ \\
\hline $\mathrm{N}(1)-\mathrm{Cu}(1)-\mathrm{O}(5)$ & $93.76(14)$ & $\mathrm{N}(3)-\mathrm{Cu}(2)-\mathrm{O}(7 \mathrm{c})$ & $94.10(13)$ & $\mathrm{N}(5)-\mathrm{Cu}(3)-\mathrm{O}(2)$ & $91.81(14)$ \\
\hline $\mathrm{N}(1)-\mathrm{Cu}(1)-\mathrm{O}(2 \mathrm{a})$ & $92.22(14)$ & $\mathrm{N}(3)-\mathrm{Cu}(2)-\mathrm{O}(5)$ & $96.95(14)$ & $\mathrm{N}(5)-\mathrm{Cu}(3)-\mathrm{O}(7 \mathrm{~d})$ & $89.84(14)$ \\
\hline $\mathrm{N}(1)-\mathrm{Cu}(1)-\mathrm{O}(4 \mathrm{~b})$ & $87.87(15)$ & $\mathrm{N}(3)-\mathrm{Cu}(2)-\mathrm{O}(10)$ & $90.00(14)$ & $\mathrm{N}(5)-\mathrm{Cu}(3)-\mathrm{O}(11)$ & $90.78(15)$ \\
\hline $\mathrm{O}(4 \mathrm{~b})-\mathrm{Cu}(1)-\mathrm{O}(2 \mathrm{a})$ & $100.00(12)$ & $\mathrm{O}(10)-\mathrm{Cu}(2)-\mathrm{O}(5)$ & $100.36(12)$ & $\mathrm{O}(11)-\mathrm{Cu}(3)-\mathrm{O}(7 \mathrm{~d})$ & $102.05(12)$ \\
\hline $\mathrm{O}(4 \mathrm{~b})-\mathrm{Cu}(1)-\mathrm{O}(5)$ & $90.22(12)$ & $\mathrm{O}(10)-\mathrm{Cu}(2)-\mathrm{O}(7 \mathrm{c})$ & $91.39(12)$ & $\mathrm{O}(11)-\mathrm{Cu}(3)-\mathrm{O}(2)$ & $87.66(11)$ \\
\hline $\mathrm{O}(5)-\mathrm{Cu}(1)-\mathrm{O}(2 \mathrm{a})$ & $168.34(11)$ & $\mathrm{O}(7 \mathrm{c})-\mathrm{Cu}(2)-\mathrm{O}(5)$ & $163.82(11)$ & $\mathrm{O}(2)-\mathrm{Cu}(3)-\mathrm{O}(7 \mathrm{~d})$ & $170.13(11)$ \\
\hline \multicolumn{2}{|c|}{ Intrachain $\mathrm{Cu}-(\mu-\mathrm{ox})-\mathrm{Cu}$} & \multicolumn{2}{|c|}{ Intrachain $\mathrm{Cu}-\left(\mu_{4}-\mathrm{ox}\right)-\mathrm{Cu}$} & \multicolumn{2}{|c|}{ Interchain shortest $\mathrm{Cu} \cdots \mathrm{Cu}$} \\
\hline $\mathrm{Cu}(1) \cdots \mathrm{Cu}(1 \mathrm{~b})$ & $5.2216(13)$ & $\mathrm{Cu}(1) \cdots \mathrm{Cu}(1 \mathrm{a})$ & $5.6913(13)$ & $\mathrm{Cu}(1) \cdots \mathrm{Cu}(2)$ & $4.1148(9)$ \\
\hline $\mathrm{Cu}(2) \cdots \mathrm{Cu}(3)$ & $5.1824(9)$ & $\mathrm{Cu}(2) \cdots \mathrm{Cu}(3 \mathrm{e})$ & $5.5166(9)$ & $\mathrm{Cu}(1 \mathrm{a}) \cdots \mathrm{Cu}(3)$ & $4.3324(9)$ \\
\hline
\end{tabular}

\footnotetext{
${ }^{1}$ Symmetry code: $(\mathrm{a})=-x+1,-y+1,-z+1 ;(\mathrm{b})=-x+1,-y,-z+1 ;(\mathrm{c})=-x+1, y+1 / 2,-z+1 / 2 ;(\mathrm{d})=x, y+1, z ;(\mathrm{e})=x, y-1, z$.
}

Table 3. Hydrogen bond distances $(\AA)$ and angles $\left(^{\circ}\right)$ for $\mathbf{1}^{1,2}$.

\begin{tabular}{ccccc}
\hline $\mathbf{D}-\mathbf{H} \cdots \mathbf{A}$ & $\mathbf{d}(\mathbf{D}-\mathbf{H})$ & $\mathbf{d}(\mathbf{H} \cdots \mathbf{A})$ & $\mathbf{d}(\mathbf{D} \cdots \mathbf{A})$ & $<$ (DHA) \\
\hline $\mathrm{N}(2)-\mathrm{H}(2) \cdots \mathrm{O}(1 \mathrm{w})$ & 0.88 & 1.8 & $2.662(5)$ & 166.1 \\
$\mathrm{O}(1 \mathrm{w})-\mathrm{H}(1 \mathrm{w} 1) \cdots \mathrm{O}(12)$ & $0.956(10)$ & $1.923(19)$ & $2.828(5)$ & $157(4)$ \\
$\mathrm{O}(1 \mathrm{w})-\mathrm{H}(1 \mathrm{w} 2) \cdots \mathrm{O}(3 \mathrm{a})$ & $0.958(10)$ & $1.796(12)$ & $2.752(5)$ & $176(4)$ \\
$\mathrm{N}(4)-\mathrm{H}(4) \cdots \mathrm{O}(11 \mathrm{f})$ & 0.88 & 1.99 & $2.800(5)$ & 152.1 \\
$\mathrm{~N}(6)-\mathrm{H}(6) \cdots \mathrm{N}(1 \mathrm{a})$ & 0.88 & 2.46 & $3.296(6)$ & 158.2 \\
\hline${ }^{1} \mathrm{D}=$ donor and $\mathrm{A}=$ acceptor $^{2}$ Symmetry code: $(\mathrm{a})=-x+1,-y+1, z+1 ;(\mathrm{f})=-x+1, y-1 / 2,-z+1 / 2$
\end{tabular}

${ }^{1} \mathrm{D}=$ donor and $\mathrm{A}=$ acceptor. $^{2}$ Symmetry code: $(\mathrm{a})=-x+1,-y+1,-z+1 ;(\mathrm{f})=-x+1, y-1 / 2,-z+1 / 2$.

\section{Results and Discussion}

\subsection{Synthesis and General Physicochemical Characterization of 1-3}

1 was prepared by the straightforward reaction of sodium oxalate with copper(II) perchlorate and 4-Hmpz in a 1:1:1.5 ox:Cu(II):4-Hmpz molar ratio at room temperature. It was isolated as a pale blue-greenish polycrystalline powder in a reasonable yield. A few 
X-ray quality crystals of $\mathbf{1}$ as thin light blue plates were grown by the slow evaporation of aqueous solutions where a mixture of oxalic acid and triethylamine in a 1:2 molar ratio was used instead of sodium oxalate. When a polycrystalline sample of $\mathbf{1}$ was reacted with $\mathrm{MeNH}_{2}$ vapor, it transformed into 2, which, in turn, became 3 after placing 2 under a vacuum (see Experimental Section). The chemical identity of $\mathbf{1}$ was determined by X-ray diffraction on single crystals, and the purity of the bulk was confirmed by XRPD (Figure S1 in the Supplementary Material). Unfortunately, all our attempts to solve the X-ray crystal structure of 2 were unsuccessful because the crystallinity retention upon methylamine adsorption was very poor (see discussion below). The methylamine adsorbates were then characterized by elemental analysis and IR spectroscopy. In fact, the IR spectra of 2 and 3 are quasi-identical, suggesting a very close structure for both methylamine adsorbates (Figure S2 in the Supplementary Material).

Absorptions at 3496m [v(O-H)], 3404m [v(N-H)], 3190w, and 2926w cm ${ }^{-1}[v(\mathrm{C}-\mathrm{H})]$ in the IR spectrum of $\mathbf{1}$ indicated the presence of water and 4-Hpmz in this compound (Figure S2a). The set of peaks assigned to the oxalate group at 1705s, 1651s, and 1599vs $\left[v_{\mathrm{as}}(\mathrm{CO})\right] ; 1358 \mathrm{~m}, 1317 \mathrm{w}$, and 1297s [ $\left.v_{\mathrm{s}}(\mathrm{CO})\right]$; and $820 \mathrm{~m}$ and $803 \mathrm{~m} \mathrm{~cm}^{-1}[\delta(\mathrm{OCO})]$ pointed out the coexistence of different bridging modes of this ligand in $\mathbf{1}$, as confirmed by the X-ray structure (see below). The occurrence of a strong absorption peak at $1418 \mathrm{~cm}^{-1}$ and a medium intensity peak at $927 \mathrm{~cm}^{-1}\left[v(\mathrm{C}-\mathrm{H})_{\text {bending }}\right.$ and $v(\mathrm{C}-\mathrm{N})_{\text {stretching }}$ modes $]$ in the IR spectra of 2 and 3 were indicative of the presence of $\mathrm{MeNH}_{2}$ in them (Figure S2b,c) [70]. Finally, the set of quasi-identical absorptions peaks attributed to the oxalate group in 2 $\left[v_{\mathrm{as}}(\mathrm{CO})=1674 \mathrm{vs}, 1652 \mathrm{~s}\right.$ and $1637 \mathrm{~s} \mathrm{~cm}^{-1}, v_{\mathrm{s}}(\mathrm{CO})=1370 \mathrm{~m}$ and $1289 \mathrm{~s} \mathrm{~cm}^{-1}$, and $\delta(\mathrm{OCO})$ $=829 \mathrm{~m}$ and $\left.807 \mathrm{~m} \mathrm{~cm}^{-1}\right]$ and $3\left[v_{\mathrm{as}}(\mathrm{CO})=1675 \mathrm{vs}, 1652 \mathrm{~s}\right.$ and $1637 \mathrm{~s} \mathrm{~cm}^{-1}, v_{\mathrm{s}}(\mathrm{CO})=1372 \mathrm{~m}$ and $1289 \mathrm{~s} \mathrm{~cm}^{-1}$, and $\delta(\mathrm{OCO})=839 \mathrm{~m}$ and $\left.806 \mathrm{~m} \mathrm{~cm}^{-1}\right]$ in their IR spectra suggests that this ligand exhibits the same bridging modes in them.

\subsection{Description of the Structure of $\mathbf{1}$}

1 crystallizes in the monoclinic space group $P 2(1) / c$, with three crystallographically independent copper(II) ions bound to a 4-Hmpz ligand of each one, two complete and two half-oxalato bridges, and one water molecule of crystallization in the asymmetric unit (Figure 1a). Its structure consists of corrugated oxalato-bridged copper(II) layers growing in the crystallographic $b c$ plane (Figure 1b). The monodentate 4-Hmpz ligands alternatively extrude above and below each oxalato-bridged copper(II) layer (Figure 1c); the water molecules of crystallization are anchored to the layers via quite strong H-bonds and confined into small hydrophobic cavities arising from the peculiar relative orientation of the three crystallographically independent 4-Hmpz moieties (Figures 1-3).

Each layer is made up by zig-zag chains of six-coordinate, axially elongated octahedral copper(II) ions, bridged by regularly alternated symmetric bis-bidentate ( $\mu$-ox$\left.\kappa^{2} \mathrm{O}^{1}, \mathrm{O}^{2}: \kappa^{2} \mathrm{O}^{2^{\prime}}, \mathrm{O}^{1^{\prime}}\right)$ and asymmetric bis-(bidentate/monodentate) $\left(\mu_{4}\right.$-ox- $\kappa O^{1}: \kappa^{2} \mathrm{O}^{1}, \mathrm{O}^{2}: \kappa \mathrm{O}^{2}$ : $\kappa^{2} \mathrm{O}^{2^{\prime}}, \mathrm{O}^{1^{\prime}}$ ) oxalate anions, featuring four short and two short/four long copper-oxygen bond distances, respectively (see Figure $1 \mathrm{a}, \mathrm{b}$ and Table 2 ). The four short [with the $\mu$-ox, values in the range 1.978(3)-2.010(3) $\AA$ ] and two short/two long [with the $\mu_{4}$-ox, values in the ranges 1.968(3)-1.969(3) and 2.287(3)-2.428(3) $\AA$, respectively] copper-to-oxygen distances regularly alternate along the chain growing direction of the chain (the crystallographic $b$ axis), while the two remaining long $\mathrm{Cu}-\mathrm{O}$ bonds [with the $\mu_{4}$-ox, values in the range 2.388(3)-2.561(3) $\AA$ ] interconnect neighboring chains along the crystallographic $c$ axis, following an $A B B A B B$ sequence (Figure $1 b)$. $A$ type chains only contain $\mathrm{Cu}(1)$ ions and the two centrosymmetric oxalate ions $\left[\mu_{4}-\mathrm{O}(1,2) \mathrm{C}(1 / 1 \mathrm{a}) \mathrm{O}(1 \mathrm{a}, 2 \mathrm{a})\right.$, symmetry code: $(\mathrm{a})=-x+1,-y$ $+1,-z+1]$ and $[\mu-\mathrm{O}(3,4) \mathrm{C}(2 / 2 \mathrm{~b}) \mathrm{O}(3 \mathrm{~b}, 4 \mathrm{~b}) ;(\mathrm{b})=-x+1,-y,-z+1]$, while those of $B$ type feature regularly alternating $\mathrm{Cu}(2)$ and $\mathrm{Cu}(3)$ ions, bridged by the non-centrosymmetric oxalate groups, $\left[\mu_{4}-\mathrm{O}(5,8) \mathrm{C}(7 / 8) \mathrm{O}(6,7)\right]$ and $[\mu-\mathrm{O}(9,11) \mathrm{C}(13 / 14) \mathrm{O}(10,12)]$. 
(a)



(b)

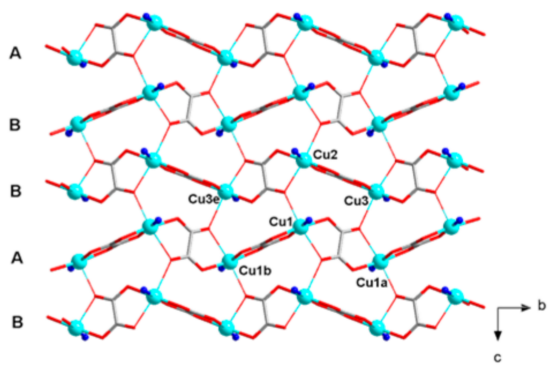

(c)

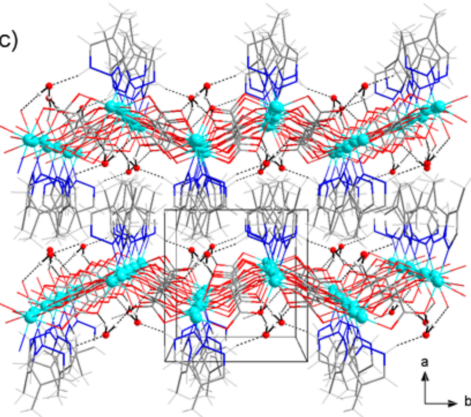

Figure 1. (a) Perspective view of a fragment of the neutral copper(II) layer of $\mathbf{1}$ with selected atom numbering. Thermal ellipsoids are drawn at the $30 \%$ probability level. (b) Projection of one corrugated oxalato-bridged copper(II) layer of $\mathbf{1}$ along the crystallographic $a$ axis (terminal pyrazole ligands are omitted for clarity). The thinner solid lines represent the long $\mathrm{Cu}-\mathrm{O}$ bond distances. (c) Perspective view of the crystal packing of $\mathbf{1}$ along the crystallographic $c$ axis showing the zippertype interpenetration of two parallel disposed layers. Hydrogen bonds are shown as dashed lines. Symmetry code: (a) $=-x+1,-y+1,-z+1 ;(\mathrm{b})=-x+1,-y,-z+1$; (c) $=-x+1, y+1 / 2,-z+1 / 2$; (d) $=x, y+1, z ;(\mathrm{e})=x, y-1, z$.

(a)

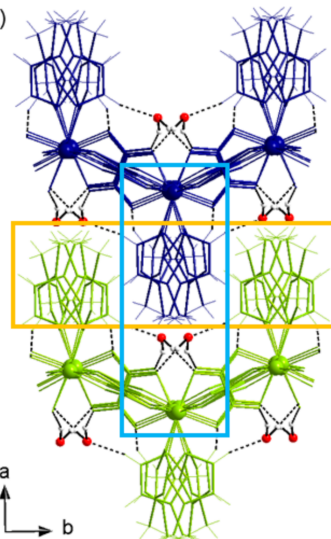

(b)

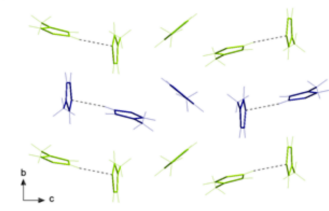

(c)

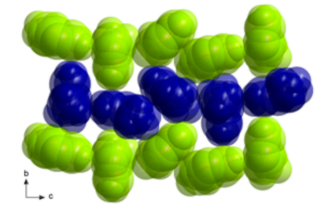

(d)

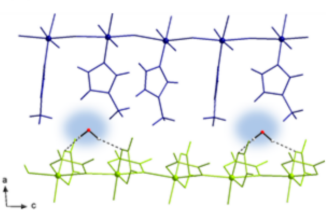

(e)

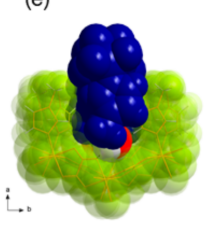

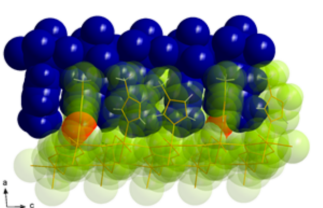

Figure 2. (a) Projection of a fragment of the crystal packing of $\mathbf{1}$ along the crystallographic $c$ axis, showing two interdigitated layers in different colors. $\mathrm{N}-\mathrm{H} \cdots \mathrm{Ow}, \mathrm{N}-\mathrm{H} \cdots \mathrm{O}_{\mathrm{ox}}$ and $\mathrm{Ow} \cdots \mathrm{O}_{\mathrm{ox}}$ type H-bonds are depicted as dashed lines. (b) Projection of the hydrophobic interlayer region [orange box in (a)] along the crystallographic $a$ axis, with the weak inter-pyrazole intralayer $\mathrm{N}-\mathrm{H} \cdots \mathrm{N} \mathrm{H}$-bond in evidence. (c) Same as (b), space-filling representation. (d) Detailed side view of a fragment of the interlayer region [sky blue box in (a)] showing the existence of very small hydrophobic cavities arising from the peculiar relative orientation of the three crystallographically independent 4-Hmpz moieties in 1. (e) Another zoomed-in view of the interlayer region along the crystallographic $c$ (left) and $b$ (right) axes, evidencing the well-defined position of the water molecules of crystallization; space-filling representation. 


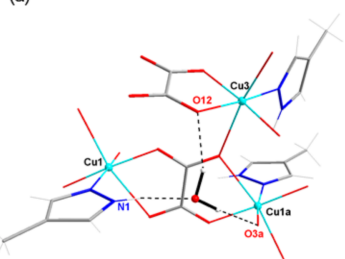

(b)

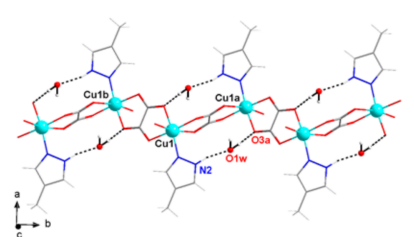

(c)

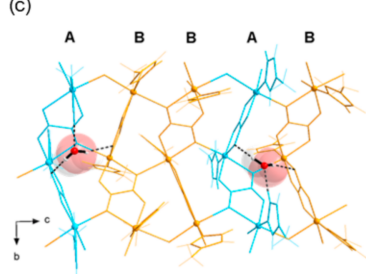

Figure 3. (a) A view of the three-fold H-bonding motif involving the water molecule of crystallization in 1. (b) A view of the H-bonds established between the water molecules of crystallization and each $A$ type chain in 1. (c) Projection along the crystallographic $a$ axis of a fragment of one oxalate-copper(II) layer, with $A$ and $B$ type chain fragments shown in different colors for clarity, aiming at illustrating both intra- and inter-chain (intralayer) $\mathrm{H}$-bonding interactions that involve the water molecule of crystallization. H-bonds are depicted as dashed lines.

The tetragonally elongated surroundings of each six-coordinate copper(II) ion in $\mathbf{1}$ comprise three oxygen atoms from two oxalate ligands and a methylpyrazole-nitrogen atom, defining the equatorial plane and two other oxalate-oxygen atoms occupying the axial positions (Figure 1a). The two axial positions at each copper(II) center correspond, thus, to either an intra- or an inter-chain $\mathrm{Cu}-\mathrm{O}$ bond (Figure $1 \mathrm{~b}$ and Table 2).

Overall, the corrugated 2D array noted in $\mathbf{1}$ is analogous to that earlier reported for the parent anhydrous compounds with either the unsubstituted $1 \mathrm{H}$-pyrazole $(\mathrm{Hpz})$ or ammonia of formula $\{\mathrm{Cu}(\mathrm{ox})(\mathrm{Hpz})\}_{n}(4)[61]$ or $\left\{\mathrm{Cu}(\mathrm{ox})\left(\mathrm{NH}_{3}\right)\right\}_{n}$ (5) [71], respectively. Within each layer of $\mathbf{1}$, the average intrachain copper-copper distances $(r)$ through the $\mu$-ox and $\mu_{4}$-ox type bridges are $\sim 5.20$ and $5.60 \AA$, respectively, while the average interchain copper-copper separation $\left(r^{\prime}\right)$ across $\mu_{4}$-ox is $\sim 4.22 \AA$ (see Table 2 ). These values agree with those noted in the crystal structures of $4\left(r \sim 5.52\right.$ and $\left.5.55 \AA ; r^{\prime} \sim 4.24 \AA\right)$ [7] and $5(r \sim 5.22$ and $5.63 \AA ; r^{\prime} \sim 4.19 \AA$ ) [71].

The close zipper-type packing of parallel disposed corrugated layers in the crystal lattice of 1 shows an interlayer separation $(d)$ of 9.9575(4) $\AA$, corresponding to the length of the crystallographic $a$ axis (Figure 1c). This value is somewhat greater than that observed in 4 [ $d=8.5694(6) \AA]$ [61], a feature which is as expected because of the presence of the bulkier 4-Hmpz ligand in $\mathbf{1} \mathrm{vs.} \mathrm{Hpz} \mathrm{in} \mathrm{4;} \mathrm{the} \mathrm{interlayer} \mathrm{separation} \mathrm{is} \mathrm{as} \mathrm{small} \mathrm{as} 4.19 \AA$ in 5 , where ammonia is the terminal ligand [71]. Indeed, the value of the calculated density for 1 is slightly lower $\left(\sim 2.05 \mathrm{~g} \mathrm{~cm}^{-3}\right)$ than that reported for $4\left(\sim 2.16 \mathrm{~g} \mathrm{~cm}^{-3}\right)$, in spite of the fact that the X-ray data collection of $\mathbf{1}$ was done at $98 \mathrm{~K}$ (its density at RT would likely be less than $2.05 \mathrm{~g} \mathrm{~cm}^{-3}$ ); moreover, the structure of $\mathbf{1}$ is capable of accommodating one water molecule of crystallization every three copper(II) ions. With respect to 4 , the bulkier 4-Hmpz moiety in $\mathbf{1}$ would induce some sort of improvement on the porosity of this family of structures, although to a quasi-negligible extent.

The closely packed 4-Hmpz ligands extruding above and below each oxalato-bridged copper(II) layer form a thick hydrophobic interlayer region (Figure 2). One of the three acidic $\mathrm{N}-\mathrm{H}$ groups is tightly hydrogen bonded to the water molecule of crystallization; the remaining two are involved in moderate to very weak intralayer $\mathrm{N}-\mathrm{H} \cdots \mathrm{O}_{\mathrm{ox}}$ and $\mathrm{N}-\mathrm{H} \cdots \mathrm{N}$ type interactions, respectively (Figure 2 and Table 3). No interlayer H-bonds involving the acidic $\mathrm{N}-\mathrm{H}$ moieties are noted, the close zipper-type packing of the parallel disposed neighboring layers being due only to hydrophobic interactions (Figure $2 b, c$ ).

The location and crystallographic occupation of the water molecules in the structure deserve particular attention. A projection of the crystal packing of $\mathbf{1}$ along the crystallographic $c$ axis (Figures 1c and 2a) appears to indicate the possible existence of tiny channels running along the same axis, suitable for hosting the solvent of crystallization. A deeper look at those supposed channels, however, confirms the non-porous character of the structure (Figure 2d). Only one of the three independent 4-Hmpz orientations is compatible with the co-existence of the terminal pyrazole ligand and the water molecules of crystallization within the hydrophobic interlayer region. As evidenced in Figure 2d,e, 
there are no channels along the $c$ axis, but only small cavities where one water molecule every three copper atoms would (and do) fit just perfectly.

The well-defined location of these tiny cavities coincides with the alternating up and down sites very close to each oxalato-copper(II) layer. Indeed, the confined water molecules of crystallization in $\mathbf{1}$ are bound to the hydrophilic layers via three strictly intralayer hydrogen bonds (Table 3 and Figure $3 a, c)$. Two of such interactions, involving the water oxygen atom as either a donor $[\mathrm{O} 1 \mathrm{w}-\mathrm{H} 1 \mathrm{w} 2 \cdots \mathrm{O} 3 \mathrm{a}=2.752(5) \AA$; (a) $=-x+1$, $-y+1,-z+1]$ or acceptor [N2-H2 $\cdots \mathrm{O} 1 \mathrm{w}=2.662(5) \AA]$ toward a bis-bidentate oxalate or an acidic N-H moiety, respectively, are specifically associated to only $A$ type chains (Figure $3 \mathrm{~b}$ ). However, the third interaction involving the water oxygen atom as a donor toward a bis-(bidentate/monodentate) oxalate group [O1w-H1w1 $\cdots \mathrm{O} 12=2.828(5) \AA]$ is established between the adjacent $A$ and $B$ chains.

\subsection{Sorption Properties}

The sorption properties of $\mathbf{1}$ toward methylamine (MA), dimethylamine (DMA), and trimethylamine (TMA) have been investigated (see the Experimental Section). The total loading after $3 \mathrm{~h}$ of exposure to an argon flow saturated with amine vapor at room temperature, expressed as the amine-to-copper molar ratio, decreased from three (MA) to one (DMA), and then to 0.1 (TMA) (Figure 4a). A remarkable color change under amine vapor was noted for both MA and DMA, being basically imperceptible for TMA (even after days of exposure), a feature which is consistent with the calculated amine loading. The kinetics of the methylamine adsorption is rather rapid for MA, and slightly slower for DMA (Figure 4a). In the case of MA, a fast loading occurs within the first minutes of exposure, with the saturation almost being reached after $\sim 20 \mathrm{~min}$.

(a)

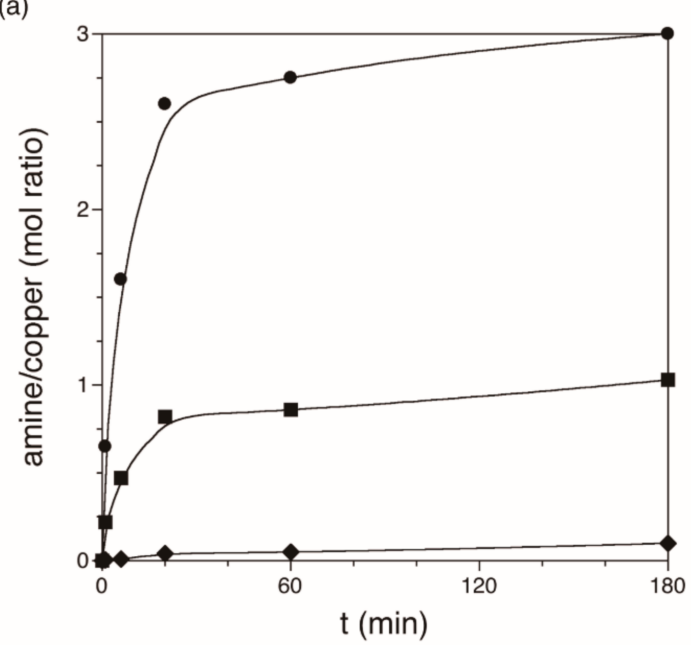

(b)



Figure 4. (a) Time profiles for the adsorption of MA $(\bullet)$, DMA $(\mathbf{\square})$, and TMA $(\boldsymbol{)})$ vapors by $\mathbf{1}$ at room temperature. The solid lines are only eye-guides. (b) XRPD of $\mathbf{1}$ (red line) and the MA adsorbates $\mathbf{2}$ (green line) and $\mathbf{3}$ (blue line). The bold black line represents the calculated XRPD of $\mathbf{1}$ from the single-crystal $X$-ray analysis.

The variation in the adsorption thermodynamics and kinetics along this series contrasts with those of the basicity and volatility of each amine, as expressed by the values of the basicity constant $\left[\mathrm{pK} \mathrm{b}_{\mathrm{b}}=3.35(\mathrm{MA}), 3.27(\mathrm{DMA})\right.$, and $4.20(\mathrm{TMA})$ at $\left.25^{\circ} \mathrm{C}\right]$ and vapor pressure [vp $=2650$ (MA), $1520(\mathrm{DMA})$, and $1610 \mathrm{~mm} \mathrm{Hg}(\mathrm{TMA})$ at $25^{\circ} \mathrm{C}$ ] [72]. The observed trend in the adsorption efficiencies (TMA $<$ DMA $<$ MA) does not coincide with the reported ones for either the basicity (TMA $<$ MA $<$ DMA) or the volatility (DMA $<$ TMA $<$ MA). This selective amine adsorption behavior, depending on the number of methyl substituents, would likely reflect both the steric constraints and the different coordination properties of the different polymethyl-substituted amines. 
Focusing on the MA adsorbates, a dramatic color change of $\mathbf{1}$ from sky to deep blue rapidly occurs upon methylamine adsorption (see Figure 5) to finally give the methylamine adsorbate 2 after $3 \mathrm{~h}$ of exposure to an argon flow saturated with MA vapor at room temperature. This transformation is accompanied by an important change in their XRPD patterns, which suggests the occurrence of a major structural rearrangement upon the adsorption of methylamine (Figure $4 \mathrm{~b}$ ). Otherwise, 2 easily loses two of the three MA molecules under vacuum for $3 \mathrm{~h}$ at room temperature to give the grayish deep blue MA adsorbate 3 , the process being accompanied by no significant change in the XRPD pattern of 3 vs. 2 (Figure $4 b$ ).

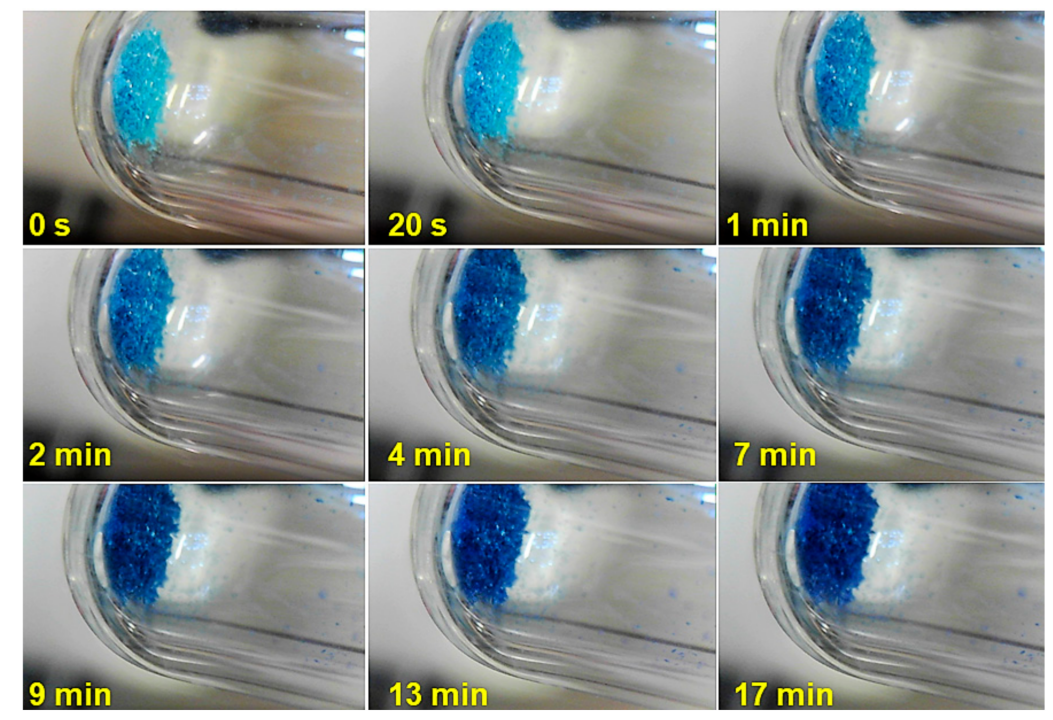

Figure 5. Sequential snapshots showing the color change of 1 under MA vapors.

Overall, these features suggest that one up from three methylamine molecules in 2 would coordinate each copper(II) ion, triggering a rearrangement of its original coordination environment, while the remaining two would possibly interact with the acidic $\mathrm{N}-\mathrm{H}$ pyrazole moieties through hydrogen bonding and/or with the 4-Hmpz ligands as a whole via hydrophobic interactions.

According to this analysis, 2 would be alternatively formulated as $\{\mathrm{Cu}(\mathrm{ox})(4-\mathrm{Hmpz})$ $\left.\left(\mathrm{MeNH}_{2}\right) \cdot 2 \mathrm{MeNH}_{2} \cdot 1 / 3 \mathrm{H}_{2} \mathrm{O}\right\}_{\mathrm{n}}$. The uptake capability of $\mathbf{1}$ toward MA is quite astonishing, considering the non-porous nature of the compound. The adsorption process is irreversible and semi-disruptive, meaning that $\mathbf{2}$ and $\mathbf{3}$ are not as crystalline as the precursor $\mathbf{1}$. This is not surprising, given that the coordination of one MA molecule would be incompatible with the original oxalato-copper(II) layered network, while the fairly stable incorporation of two extra MA molecules would contribute to the unsettling of the original zipper-type close packing. On the other hand, the fact that the water molecule of crystallization is kept would indicate the persistence of relatively strong hydrogen bonds with the oxalate oxygen atoms and/or the 4-Hmpz acidic N-H moieties, even after structural rearrangement.

\subsection{Magnetic Properties of $\mathbf{1}-\mathbf{3}$}

The $\chi_{M}$ and $\chi_{M} T$ vs. $T$ plots for $1-3\left[\chi_{M}\right.$ being the molar magnetic susceptibility per copper(II) ion] show a concomitant change of the magnetic properties from strong (1) to weak (2 and 3) antiferromagnetic coupling (Figure 6). Therefore, the $\chi_{M^{T}} T$ values at room temperature increased from $0.21 \mathrm{~cm}^{3} \mathrm{~mol}^{-1} \mathrm{~K}(1)$ to $0.40(2)$ and $0.39 \mathrm{~cm}^{3} \mathrm{~mol}^{-1} \mathrm{~K}$ (3). They were well or slightly below than that expected for a magnetically isolated spin doublet $\left(\chi_{\mathrm{M}} T=0.41 \mathrm{~cm}^{3} \mathrm{~mol}^{-1} \mathrm{~K}\right.$ with $\left.g=2.1\right)$. Upon cooling, $\chi_{\mathrm{M}} T$ decreased continuously for $\mathbf{1}$, and it vanished around $50 \mathrm{~K}$. In the case of 2 and 3, the values of $\chi_{\mathrm{M}} T$ remained constant down to 50 (2) and $25 \mathrm{~K}(3)$, and then decreased smoothly to reach 0.15 (2) and $0.34 \mathrm{~cm}^{3}$ $\mathrm{mol}^{-1} \mathrm{~K}(3)$ at $2.0 \mathrm{~K}$ (Figure 6a). Besides, $\chi_{\mathrm{M}}$ showed a broad maximum around room 
temperature for $\mathbf{1}$, whereas no maximum of the magnetic susceptibility occured for $\mathbf{2}$ and 3 down to $2.0 \mathrm{~K}$ (Figure 6b). Overall, these features support the occurrence of a fast and complete, irreversible solid-state transformation during the methylamine sorption process.
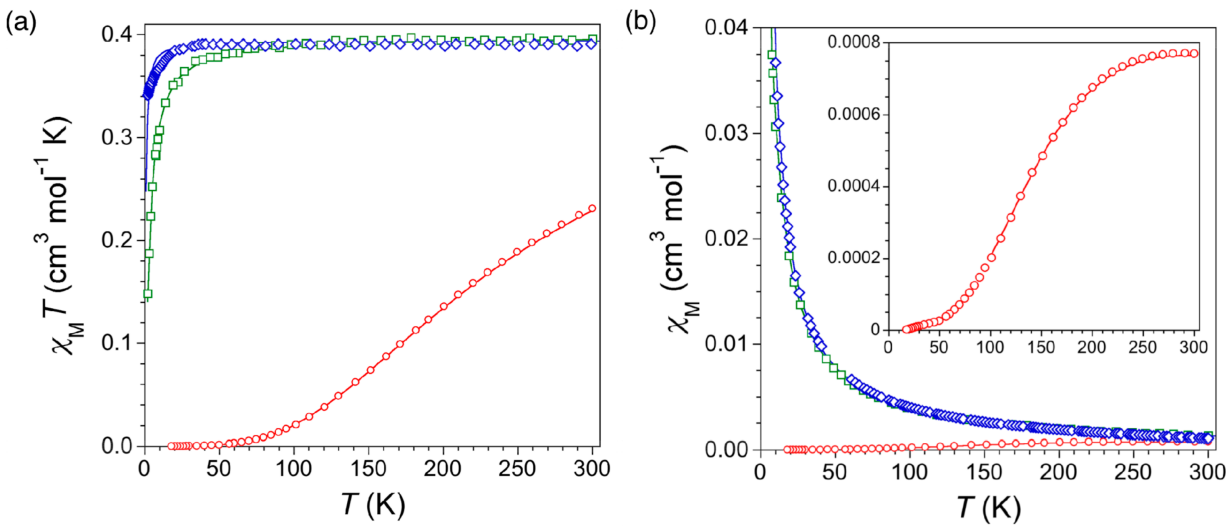

Figure 6. Temperature dependence of $\chi_{\mathrm{M}} T(\mathbf{a})$ and $\chi_{\mathrm{M}}(\mathbf{b})$ of $\mathbf{1}(\bigcirc)$ and the MA adsorbates $\mathbf{2}(\square)$ and $3(\diamond)$. The inset in $(\mathbf{b})$ aims to show how the maximum of $\chi_{\mathrm{M}}$ of $\mathbf{1}(\bigcirc)$ occured in the vicinity of $300 \mathrm{~K}$. The solid lines are the best-fit curves (see text).

Bearing in mind the above results, the analysis of the magnetic susceptibility data for 1-3 was carried out by means of the Hatfield expression derived from the spin Hamiltonian for an alternating copper(II) chain, $\boldsymbol{H}=-J \sum\left(\boldsymbol{S}_{\mathbf{C u 2 i}} \cdot S_{\mathbf{C u 2 i - 1}}+\alpha S_{\mathbf{C u 2 i}} \cdot S_{\mathbf{C u 2 i}+1}\right)+g \beta H \sum S_{\mathbf{i}}$ $\left(S_{\mathrm{Cu} 2 \mathrm{i}}=S_{\mathrm{Cu}}=\frac{1}{2}\right)$ (see Scheme 1), where $J$ and $\alpha J$ are the two different antiferromagnetic intrachain coupling parameters ( $\alpha$ being the alternation parameter) and $g$ is the average Landé factor of the copper(II) ions $\left(g=g_{2 i}=g_{\mathrm{Cu}}\right)$ [73]. Least-squares fits of the experimental data gave $-J=322(2)(\mathbf{1}), 3.20(2)(2)$, and $0.56(4) \mathrm{cm}^{-1}(3)$, with $\alpha=0.02(1)(1), 0.92(1)$ (2) and $0.90(1)(3)$, and $g=2.07(1)(1), 2.06(1)(2)$ and 2.05(1) (3). The theoretical curves match very well the experimental ones for all three compounds (solid lines in Figure 6).

The calculated $-J$ value for $\mathbf{1}$ is comparable to those found for the aforementioned pyrazole and ammonia analogues 4 and $5\left(-J=312\right.$ and $\left.265 \mathrm{~cm}^{-1}\right)$, which possess similar structural parameters [61,71]. Otherwise, the large decrease of the $-J$ value for 2 and 3 relative to 1 indicates the occurrence of a magnetic orbital reversal upon methylamine adsorption [74-76], as illustrated in Scheme 1. Hence, the overlap between the $\mathrm{d}\left(x^{2}-y^{2}\right)$ type magnetic orbitals of the axially elongated octahedral $\mathrm{Cu}^{\mathrm{II}}$ ions varies from very strong (1) to weak but non-negligible (2 and 3) for a coplanar and a perpendicular disposition of the metal equatorial planes with respect to the mean plane of the symmetric or asymmetric bridging oxalate, respectively (Scheme 1a,b). This magnetic switching behavior can likely be attributed to methylamine coordination to the metal ion in both adsorbates 2 and 3 , as earlier found in the related pair of regular $\mu$-oxalatocopper(II) chains of formulae $\left\{\mathrm{Cu}(\mathrm{ox}) \cdot 1 / 3 \mathrm{H}_{2} \mathrm{O}\right\}_{n}(6)\left(\mathrm{J}=-291 \mathrm{~cm}^{-1}\right)$ and $\left\{\mathrm{Cu}(\mathrm{ox})\left(\mathrm{NH}_{3}\right)_{2} \cdot 2 \mathrm{H}_{2} \mathrm{O}\right\}_{n}(7)\left(J=-15.4 \mathrm{~cm}^{-1}\right)[74]$. 


\section{$\mathrm{Cu}_{2 \mathrm{i}-1} \stackrel{J}{-} \mathrm{Cu}_{2 \mathrm{i}} \stackrel{\alpha J}{-} \mathrm{Cu}_{2 \mathrm{i}+1}$}

(a)



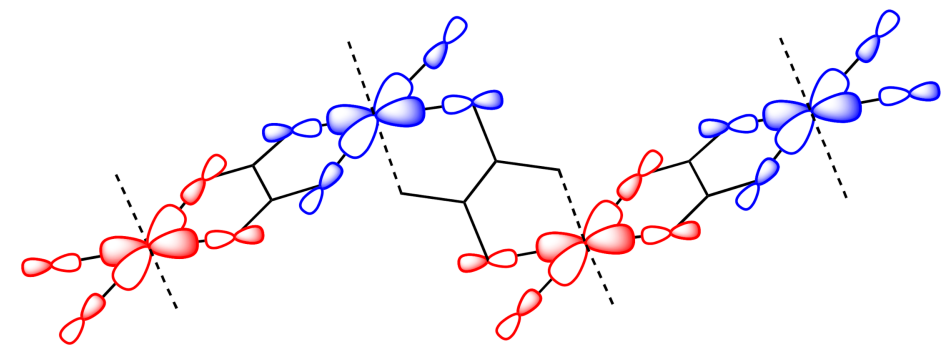

(b)

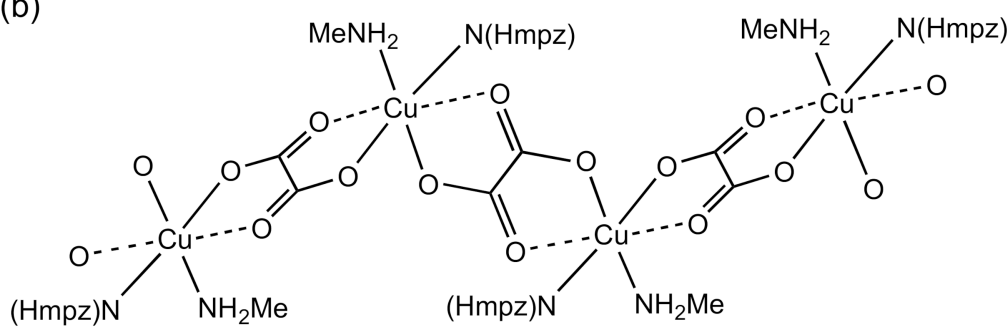

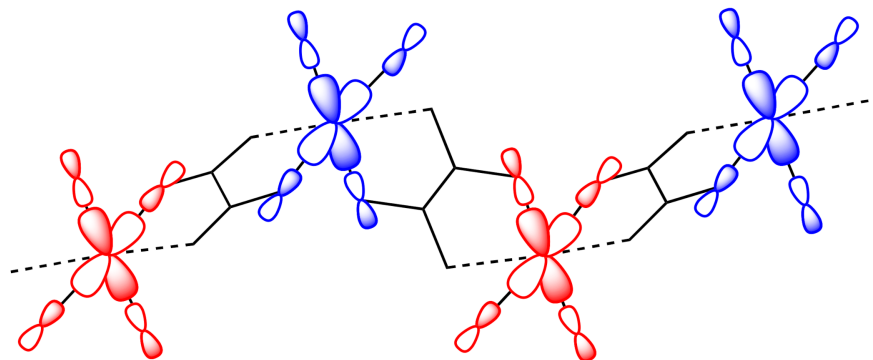

Scheme 1. Illustration of the magnetic coupling model for an alternating copper(II) chain showing the relative orientation of the magnetic orbitals centered on each copper(II) ion for $\mathbf{1}$ (a), relative to 2 and 3 (b). The solid and dashed lines represent short and long metal-ligand bonds, respectively.

\section{Conclusions}

In summary, a new oxalato-bridged copper(II)-pyrazole coordination polymer has been obtained from the copper(II)-mediated self-assembly of oxalate and 4-Hmpz in water under mild conditions. This new heteroleptic 2D copper(II) coordination polymer features a non-porous, interdigitated, zipper-type layered structure with acidic N-H sites from the terminal 4-methyl substituted pyrazole ligands within the interlayer space, in close proximity to the main hydrophilic oxalate-copper(II) region. In spite of its very dense crystal packing, 1 exhibits a fast and selective adsorption for polymethyl-substituted amines, which is accompanied by a dynamic switching behavior with dramatic changes in both the color and magnetic coupling following a structural rearrangement upon the adsorption of methylamine. Such features (structural modulation together with external control of the optical and magnetic properties), combined with the easy self-assembling 
and potential addressing as thin films over a variety of surfaces, make this novel class of 2D multifunctional magnetic materials suitable candidates for obtaining switching optical and magnetic devices for chemical sensing. This might allow for system optimization with a special focus on improving the porosity of the supramolecular 3D network and/or expanding the coordination capabilities of the metal ion.

Supplementary Materials: The following figures are available online at https:/ / www.mdpi.com/ article/10.3390/magnetochemistry7050065/s1, Figure S1: XRPD pattern from a bulk sample of $\mathbf{1}$ and the generated pattern from its X-ray single-crystal diffraction data; Figure S2: IR spectra of $\mathbf{1}(\mathrm{a}), \mathbf{2}$ (b), and 3 (c).

Author Contributions: I.C., N.M. (Nadia Marino), and M.J. conceived the project; I.C., N.M. (Nadia Marino), and R.R.-G. designed and discussed the experiments; M.L.C., M.O.-A., and A.P.-Á. synthesized and characterized the complexes; N.M. (Nadia Marino) and G.D.M. carried out the crystallographic study; N.M. (Nicolás Moliner), F.L., and R.R.-G. performed the magnetic study; R.R.-G., N.M. (Nadia Marino), and M.J. wrote and/or reviewed the manuscript with contributions. All authors have read and agreed to the published version of the manuscript.

Funding: This research was funded by the Spanish MICIU (Project PID2019-109735GB-I00) and the Generalitat Valenciana (AICO/2020/183). We also acknowledge the financial support from the European Commission (FSE, Fondo Sociale Europeo) and the Calabria Region for a fellowship grant N.M. (Nadia Marino), M.O.-A. and A.P.-Á. thank the MICIU for doctoral grants.

Institutional Review Board Statement: Not applicable.

Informed Consent Statement: Not applicable.

Data Availability Statement: The data are available by corresponding authors.

Acknowledgments: Thanks are also due to the Servei Central de Suport a la Investigació Experimental de la Universitat de València (SCSIE-UV) for its assistance with the analytical characterization of the compounds.

Conflicts of Interest: The authors declare no conflict of interest.

Sample Availability: Samples of 1-3 are available from the authors.

\section{References}

1. Ouahab, L. (Ed.) Multifunctional Molecular Materials; Pan Standford Publishing: Singapore, 2013.

2. Sieklucka, B.; Pinkowicz, D. (Eds.) Molecular Magnetic Materials: Concepts and Applications; Wiley-VCH: Weinheim, Germany, 2017.

3. Day, P. New transparent ferromagnets. Acc. Chem. Res. 1979, 12, 236-243. [CrossRef]

4. Day, P.; Kurmoo, M. Molecular magnetic semiconductors, metals and superconductors: BEDT-TTF salts with magnetic anions. J. Mater. Chem. 1997, 7, 1291-1295. [CrossRef]

5. Alivisatos, P.; Barbara, P.F.; Castleman, A.W.; Chang, J.; Dixon, D.A.; Klein, M.L.; McLendon, G.L.; Miller, J.S.; Ratner, M.A.; Rossky, P.J.; et al. From molecules to materials: Current trends and future directions. Adv. Mater. 1998, 10, 1297-1336. [CrossRef]

6. Dujardin, E.; Mann, S. Morphosynthesis of molecular magnetic materials. Adv. Mater. 2004, 16, 1125-1129. [CrossRef]

7. Coronado, E.; Day, P. Magnetic molecular conductors. Chem. Rev. 2004, 104, 5419-5448. [CrossRef]

8. Coronado, E.; Gatteschi, D. Trends and challenges in molecule-based magnetic materials. J. Mater. Chem. 2006, 16, $2513-2515$.

9. Pinkowicz, D.; Czarnecki, B.; Reczynski, M.; Arczinski, M. Multifunctionality in molecular magnetism. Sci. Prog. 2015, 98, 346-378. [CrossRef]

10. Ferrando-Soria, J.; Vallejo, J.; Castellano, M.; Martínez-Lillo, J.; Pardo, E.; Cano, J.; Castro, I.; Lloret, F.; Ruiz-García, R.; Julve, M. Molecular magnetism, quo vadis? A historical perspective from a coordination chemist viewpoint. Coord. Chem. Rev. 2017, 339, 17-103. [CrossRef]

11. Coronado, E. Molecular magnetism: From chemical design to spin control in molecules, materials and devices. Nat. Rev. Mater. 2020, 5, 87-104. [CrossRef]

12. Kepert, C.J. Advanced functional properties in nanoporous coordination framework materials. Chem. Commun. 2006, 695-700. [CrossRef]

13. Maspoch, D.; Ruiz-Molina, D.; Veciana, J. Old materials with new tricks: Multifunctional open-framework materials. Chem. Soc. Rev. 2007, 36, 770-818. [CrossRef]

14. Pardo, E.; Ruiz-García, R.; Cano, J.; Ottenwaelder, X.; Lescouëzec, R.; Journaux, Y.; Lloret, F.; Julve, M. Ligand design for multidimensional magnetic materials: A metallosupramolecular perspective. Dalton Trans. 2008, 2780-2805. [CrossRef]

15. Kurmoo, M. Magnetic metal-organic frameworks. Chem. Soc. Rev. 2009, 38, 1353-1379. [CrossRef] 
16. Dul, M.-C.; Pardo, E.; Lescouëzec, R.; Journaux, Y.; Ferrando-Soria, J.; Ruiz-García, R.; Cano, J.; Julve, M.; Lloret, F.; Cangussu, D.; et al. Supramolecular coordination chemistry of aromatic polyoxalamide ligands: A metallosupramolecular approach toward functional magnetic materials. Coord. Chem. Rev. 2010, 254, 2281-2296. [CrossRef]

17. Dechambenoit, P.; Long, J.R. Microporous magnets. Chem. Soc. Rev. 2011, 40, 3249-3265. [CrossRef]

18. Muñoz, M.C.; Real, J.A. Thermo-, piezo-, phot- and chemo-switchable spin crossover iron(II)-metallocyanate based coordination polymers. Coord. Chem. Rev. 2011, 255, 2068-2093. [CrossRef]

19. Coronado, E.; Mínguez-Espallargas, G. Dynamic magnetic MOFs. Chem. Soc. Rev. 2013, 42, 1525-1539. [CrossRef]

20. Grancha, T.; Ferrando-Soria, J.; Castellano, M.; Julve, M.; Pasán, J.; Armentano, D.; Pardo, E. Oxamato-based coordination polymers: Recent advances in multifunctional magnetic materials. Chem. Commun. 2014, 50, 7569-7585. [CrossRef]

21. Coronado, E.; Mínguez-Espallargas, G. magnetic functionalities in MOFs: From the framework to the pore. Chem. Soc. Rev. 2018, $47,533-557$.

22. Thorarinsdottir, A.E.; Harris, T.D. Metal-organic framework magnets. Chem. Rev. 2020, 120, 8716-8789. [CrossRef]

23. Kreno, L.E.; Leong, K.; Farha, O.K.; Allendorf, M.; Van Duyne, R.P.; Hupp, J.T. Metal-organic framework materials as chemical sensors. Chem. Rev. 2012, 112, 1105-1125. [CrossRef] [PubMed]

24. Kaushik, A.; Kumar, R.; Arya, S.K.; Nair, M.; Malhotra, B.D.; Bhansali, S. Organic-inorganic hybrid nanocomposite-based gas sensors for environmental monitoring. Chem. Rev. 2015, 115, 4571-4606. [CrossRef]

25. Kumar, P.; Deep, A.; Kim, K.-H.; Brown, R.J.C. Coordination polymers: Opportunities and challenges for monitoring volatile organic compounds. Prog. Polym. Sci. 2015, 45, 102-118. [CrossRef]

26. Yi, F.-Y.; Chen, D.; Wu, M.-K.; Han, L.; Jiang, H.-L. Chemical sensors based on metal-organic frameworks. ChemPlusChem 2016, 81, 675-690. [CrossRef] [PubMed]

27. Kumar, V.; Kim, K.-H.; Kumar, P.; Jeon, B.-H.; Kim, J.-C. Functional hybrid nanostructure materials: Advanced strategies for sensing applications toward volatile organic compounds. Coord. Chem. Rev. 2017, 342, 80-105. [CrossRef]

28. Zhang, Y.; Yuan, S.; Day, G.; Wang, X.; Yang, X.; Zhou, H.-C. Luminescent sensors based on metal-organic frameworks. Coord. Chem. Rev. 2018, 354, 28-45. [CrossRef]

29. Dolgopolova, E.A.; Rice, A.M.; Martin, C.R.; Shustova, N.B. Photochemistry and photophysics of MOFs: Steps towards MOFbased sensing enhancements. Chem. Soc. Rev. 2018, 47, 4710-4728. [CrossRef]

30. Wang, H.; Lusting, W.P.; Li, J. Sensing and capture of toxic and hazardous gases and vapors by metal-organic frameworks. Chem. Soc. Rev. 2018, 47, 4729-4756. [CrossRef] [PubMed]

31. Zhao, S.-N.; Wang, G.; Poelman, D.; Van Der Voort, P. Luminescent lanthanide MOFs: A unique platform for chemical sensing. Materials 2018, 11, 572. [CrossRef]

32. Rasheed, T.; Nabeel, F. Luminescent metal-organic frameworks as potential sensory materials for various environmental toxic agents. Coord. Chem. Rev. 2019, 401, 213065. [CrossRef]

33. Wang, P.-L.; Xie, L.-H.; Joseph, E.A.; Li, J.-R.; Su, X.-O.; Zhou, H.-C. Metal-organic frameworks for food safety. Chem. Rev. 2019, 119, 10638-10690. [CrossRef] [PubMed]

34. Lai, C.; Wang, Z.; Qin, L.; Fu, Y.; Li, B.; Zhang, M.; Liu, S.; Li, L.; Yi, H.; Liu, X.; et al. Metal-organic frameworks as burgeoning materials for the capture and sensing of indoor VOCs and radon gases. Coord. Chem. Rev. 2021, 427, 213565. [CrossRef]

35. Ohba, M.; Yoneda, K.; Agustí, G.; Muñoz, M.C.; Gaspar, A.B.; Real, J.A.; Yamasaki, M.; Ando, H.; Nakao, Y.; Sakaki, S.; et al. Bidirectional chemo-switching of spin state in a microporous framework. Angew. Chem. Int. Ed. 2009, 48, 4767-4771. [CrossRef] [PubMed]

36. Agustí, G.; Ohtani, R.; Yoneda, K.; Gaspar, A.B.; Ohba, M.; Sánchez-Royo, J.F.; Muñoz, M.C.; Kitagawa, S.; Real, J.A. Oxidative addition of halogens on open metal sites in a microporous spin-crossover coordination polymer. Angew. Chem. Int. Ed. 2009, 48, 8944-8947. [CrossRef]

37. Ohba, M.; Yoneda, K.; Kitagawa, S. Guest-responsive porous magnetic frameworks using polycyanometallates. CrystEngComm 2010, 12, 159-165. [CrossRef]

38. Ohtani, R.; Yoneda, K.; Furukawa, S.; Horike, N.; Kitagawa, S.; Gaspar, A.B.; Muñoz, M.C.; Real, J.A.; Ohba, M. Precise control and consecutive modulation of spin transition temperature using chemical migration in porous coordination polymers. J. Am. Chem. Soc. 2011, 133, 8600-8605. [CrossRef]

39. Coronado, E.; Giménez-Marqués, M.; Mínguez-Espallargas, G.; Brammer, L. Tuning the magneto-structural properties of non-porous coordination polymers by $\mathrm{HCl}$ chemisorption. Nat. Commun. 2012, 3, 1827. [CrossRef]

40. Ferrando-Soria, J.; Ruiz-García, R.; Cano, J.; Stiriba, S.-E.; Vallejo, J.; Castro, I.; Julve, M.; Lloret, F.; Amorós, P.; Pasán, J.; et al. Reversible solvatomagnetic switching in a spongelike manganese(II)-copper(II) open framework with a pillared square/octagonal layer architecture. Chem. Eur. J. 2012, 18, 1608-1617. [CrossRef]

41. Ferrando-Soria, J.; Serra-Crespo, P.; de Lange, M.; Gascon, J.; Kapteijn, F.; Julve, M.; Cano, J.; Lloret, F.; Pasán, J.; Ruiz-Pérez, C.; et al. Selective gas and vapor sorption and magnetic sensing by an isoreticular mixed-metal-organic framework. J. Am. Chem. Soc. 2012, 134, 15301-15304. [CrossRef] [PubMed]

42. Ferrando-Soria, J.; Khajavi, H.; Serra-Crespo, P.; Gascon, J.; Kapteijn, F.; Julve, M.; Lloret, F.; Pasán, J.; Ruiz-Pérez, C.; Journaux, Y.; et al. Highly selective chemical sensing in a luminiscent nanoporous magnet. Adv. Mater. 2012, 24, 5625-5629. [CrossRef]

43. Vallejo, J.; Fortea-Pérez, F.R.; Pardo, E.; Benmansour, S.; Castro, I.; Krzystek, J.; Armentano, D.; Cano, J. Guest-dependent single-ion magnet behaviour in a cobalt(II) metal-organic framework. Chem. Sci. 2016, 7, 2286-2293. [CrossRef] [PubMed] 
44. Zhang, W.; Wang, D.; Zhu, L.; Zhai, F.; Weng, L.; Sun, J.; Ling, Y.; Chen, Z.; Zhou, Y. HCl chemisorption-induced drastic magnetostructural transformation in a layered cobalt-phosphonotriazolate coordination polymer. Dalton Trans. 2016, 45, 10510-10513. [CrossRef] [PubMed]

45. Perlepes, P.; Oyarzabal, I.; Mailman, A.; Yquel, M.; Platunov, M.; Dovgaliuk, I.; Rouzières, M.; Négrier, P.; Mondieig, D.; Suturina, E.A.; et al. Metal-organic magnets with large coercivity and ordering temperatures up to $242{ }^{\circ} \mathrm{C}$. Science 2020, 370, 587-592. [CrossRef]

46. Turo-Cortes, R.; Bartual-Murgui, C.; Castells-Gil, J.; Muñoz, M.C.; Martí-Gastaldo, C.; Real, J.A. Reversible guest-induced gate-opening with multiplex spin crossover responses in two-dimensional Hofmann clathrates. Chem. Sci. 2020, 11, 11224-11234. [CrossRef]

47. Piñeiro-López, L.; Valverde-Muñoz, F.-J.; Trzop, E.; Muñoz, M.C.; Seredyuk, M.; Castells-Gil, J.; da Silva, I.; Martí-Gastaldo, C.; Collet, E.; Real, J.A. Guest induced reversible on-off switching of elastic frustration in a 3D spin crossover coordination polymer with room temperature hysteretic behaviour. Chem. Sci. 2021, 12, 1317-1326. [CrossRef]

48. Cingolani, A.; Galli, S.; Masciocchi, N.; Pandolfo, L.; Pettinari, C.; Sironi, A. Sorption-desorption behavior of bispirazolatocopper(II) 1D coordination polymers. J. Am. Chem. Soc. 2005, 127, 6144-6145. [CrossRef]

49. Qiu, L.-G.; Li, Z.-Q.; Wu, Y.; Wang, W.; Xu, T.; Jiang, X. Facile synthesis of nanocrystals of a microporous metal-organic framework by an ultrasonic method and selective sensing of orgonoamines. Chem. Commun. 2008, 3642-3644. [CrossRef] [PubMed]

50. Bencini, A.; Casarin, M.; Forrer, D.; Franco, L.; Garau, F.; Masciocchi, N.; Pandolfo, L.; Pettinari, C.; Ruzzi, M.; Vittadini, A. Magnetic properties and vapochromic reversible guest-induced transformation in a bispyrazolato copper(II) polymer: An experimental and dispersion-corrected density functional theory study. Inorg. Chem. 2009, 48, 4044-4051. [CrossRef]

51. Zou, X.; Zhu, G.; Hewitt, I.J.; Sun, F.; Qiu, S. Synthesis of a metal-organic framework film by direct conversion technique for VOCs sensing. Dalton Trans. 2009, 3009-3013. [CrossRef]

52. Chen, J.; Yi, F.-Y.; Yu, H.; Jiao, S.; Pang, G.; Sun, Z.-M. Fast response and highly selective sensing of amine vapors using a luminiscent coordination polymer. Chem. Commun. 2014, 50, 10506-10509. [CrossRef]

53. Mallick, A.; Garai, B.; Addicoat, M.A.; St. Petkov, P.; Heine, T.; Banerjee, R. Solid state organic amine detection in a photochromic porous metal-organic framework. Chem. Sci. 2015, 6, 1420-1425. [CrossRef]

54. Tan, B.; Chen, C.; Cai, L.-X.; Zhang, Y.-J.; Huang, X.-Y.; Zhang, J. Introduction of Lewis acidic and redox-active sites into a porous framework for ammonia capture with visual color response. Inorg. Chem. 2015, 54, 3456-3461. [CrossRef]

55. Chen, C.; Cai, L.-X.; Tan, B.; Zhang, Y.-J.; Yang, X.-D.; Zhang, J. Ammonia detection by using flexible Lewis acidic sites in luminiscent porous frameworks constructed from a bipyridinium derivative. Chem. Commun. 2015, 51, 8189-8192. [CrossRef] [PubMed]

56. Campbell, M.G.; Sheberla, D.; Liu, S.F.; Swager, T.M.; Dinca, M. $\mathrm{Cu}_{3}$ (hexaiminotriphenylene) ${ }_{2}$ : An electrically conductive 2D metal-organic framework for chemiresistive sensing. Angew. Chem. Int. Ed. 2015, 54, 4349-4352. [CrossRef] [PubMed]

57. Shen, X.; Yan, B. A novel fluorescence probe for sensing organic amine vapors from a Eu ${ }^{3+} \beta$-diketonate functionalized bio-MOF-1 hybrid system. J. Mater. Chem. C 2015, 3, 7038-7044. [CrossRef]

58. Takahashi, A.; Tanaka, H.; Parajuli, D.; Nakamura, T.; Minami, K.; Sugiyama, Y.; Hakuta, Y.; Ohkoshi, S.; Kawamoto, T. Historical pigment exhibiting ammonia gas capture beyond standard adsorbents with adsorption sites of two kinds. J. Am. Chem. Soc. 2016, 138, 6376-6379. [CrossRef] [PubMed]

59. Zhao, S.-S.; Yang, J.; Liu, Y.-Y.; Ma, J.-F. Fluorescent aromatic tag-functionalized MOFs for highly selective sensing of metal ions and small organic molecules. Inorg. Chem. 2016, 5, 2261-2273. [CrossRef]

60. Yang, N.-N.; Sun, W.; Xi, F.-G.; Sui, Q.; Chen, L.-J.; Gao, E.-Q. Postsynthetic N-methylation making a metal-organic framework responsive to alkylamines. Chem. Commun. 2017, 53, 1747-1750. [CrossRef]

61. Świtlicka-Olszewska, A.; Machura, B.; Mroziński, J.; Kalińska, N.; Kruszynski, R.; Penkala, M. Effect of N-donor ancillary ligands on structural and magnetic properties of oxalate copper(II) complexes. New J. Chem. 2014, 38, 1611-1626. [CrossRef]

62. Calatayud, M.L.; Orts-Arroyo, M.; Julve, M.; Lloret, F.; Marino, N.; De Munno, G.; Ruiz-García, R.; Castro, I. Magneto-structural correlations in asymmetric oxalato-bridged dicopper(II) complexes with polymethyl-substituted pyrazole ligands. J. Coord. Chem. 2017, 71, 657-674. [CrossRef]

63. Castro, I.; Calatayud, M.L.; Orts-Arroyo, M.; Moliner, N.; Marino, N.; Lloret, F.; Ruiz-García, R.; De Munno, G.; Julve, M. Ferroand Antiferromagnetic Interactions in Oxalato-Centered Inverse Hexanuclear and Chain Copper(II) Complexes with Pyrazole Derivatives. Molecules 2021, 26, 2792. [CrossRef]

64. Bruker. SMART; Data Collection Software (Version 4.050); Siemens Analytical Instruments Inc.: Madison, WI, USA, 1996.

65. Bruker. SAINT; (Version 7.68A); Bruker AXS Inc.: Madison, WI, USA, 2009.

66. Bruker. SADABS; (Version 2008/1); Bruker AXS Inc.: Madison, WI, USA, 2008.

67. Sheldrick, G.M. A short history of SHELX. Acta Cryst. 2008, A64, 112-122. [CrossRef]

68. Sheldrick, G.M. Crystal structure refinement with SHELXL. Acta Cryst. 2015, C71, 3-8.

69. Diamond Software; Version 4.6.4 (2021); Crystal Impact Kreuzherrenstr: Bonn, Germany, 2021.

70. Zeroka, D.; Jensen, J.O. Infrared spectra of some isotopomers of methylamine and the methylammonium ion: A theoretical study. J. Mol. Struct. 1998, 425, 181-192. [CrossRef]

71. Cavalca, L.; Villa, A.C.; Manfredotti, A.G.; Tomlinson, A.A.G. Crystal, molecular, and electronic structure of catena- $\mu$-oxalatoammine-copper(II). J. Chem. Soc. Dalton Trans. 1972, 3, 391-395. [CrossRef] 
72. PubChem Database. CID Numbers: 6329 (Methylamine), 674 (Dimethylamine), and 1146 (Trimethylamine); National Center for Biotechnology Information (NCBI): Bethesda, MD, USA.

73. Hall, J.W.; Marsh, W.E.; Weller, R.R.; Hatfield, W.E. Exchange coupling in the alternating-chain compounds catena-di- $\mu$-chloro-bis(4methylpyridine)copper(II), catena-di- $\mu$-bromo-bis( $N$-methylimidazole)copper(II), catena-[hexadione bis(thiosemicarbazonato)] copper(II), and catena-[octanedione bis(thiosemicarbazonato)]copper(II). Inorg. Chem. 1981, 20, 1033-1037.

74. Girerd, J.J.; Kahn, O.; Verdaguer, M. Orbital reversal in (oxalato)copper(II) linear chains. Inorg. Chem. 1980, 19, 274-276. [CrossRef]

75. Julve, M.; Verdaguer, M.; Gleizes, A.; Philoche-Levisalles, M.; Kahn, O. Design of $\mu$-oxalato copper(II) binuclear complexes exhibiting expected magnetic properties. Inorg. Chem. 1984, 23, 3808-3818. [CrossRef]

76. Journaux, Y.; Sletten, J.; Kahn, O. Tunable interactions in $\mu$-oxamido copper(II) binuclear complexes. Inorg. Chem. 1985, 24, 4063-4069. [CrossRef] 